\title{
EUDORA WELTY
}


Women Writers

General Editors: Eva Figes and Adele King

\section{Published titles:}

Sylvia Plath, Susan Bassnett

Fanny Burney, Judy Simons

Christina Stead, Diana Brydon

Charlotte Bronte, Pauline Nestor

Margaret Atwood, Barbara Hill Rigney

Eudora Welty, Louise Westling

Anne Bronte, Elizabeth Langland

\section{Forthcoming:}

Fane Austen, Meenakshi Mukherjee

Elizabeth Barrett Browning, Majorie Stone Elizabeth Bowen, Phyllis Lassner

Emily Bronte, Lyn Pykett

Ivy Compton Burnett, Kathy Gentile

Willa Cather, Susie Thomas

Colette, Diana Holmes

Emily Dickinson, Joan Kirkby

George Eliot, Kristin Brady

Mrs Gaskell, Jane Spencer

Doris Lessing, Barbara Hill Rigney

Katherine Mansfield, Diane DeBell

Christina Rossetti, Linda Marshall

fean Rhys, Carol Rumens

Stevie Smith, Catherine Civello

Muriel Spark, Judith Sproxton

Edith Wharton, Katherine Joslin

Women in Romanticism, Meena Alexander

Virginia Woolf, Clare Hanson 


\section{Women Writers}
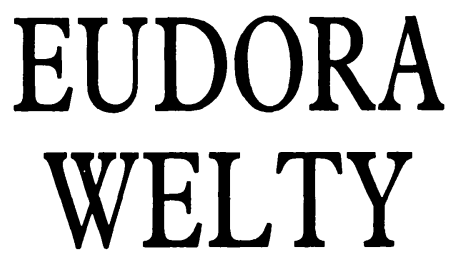

\section{Louise Westling}

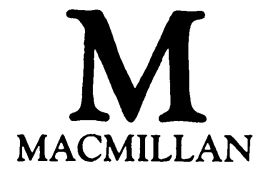


All rights reserved. No reproduction, copy or transmission of this publication may be made without written permission.

No paragraph of this publication may be reproduced, copied or transmitted save with written permission or in accordance with the provisions of the Copyright Act 1956 (as amended), or under the terms of any licence permitting limited copying issued by the Copyright Licensing Agency, 33-4 Alfred Place, London WC1E 7DP.

Any person who does any unauthorised act in relation to this publication may be liable to criminal prosecution and civil claims for damages.

First published 1989

Published by

MACMILLAN EDUCATION LTD

Houndmills, Basingstoke, Hampshire RG21 2XS

and London

Companies and representatives

throughout the world

British Library Cataloguing in Publication Data

Westling, Louise

Eudora Welty - (Women writers).

1. Fiction in English. American writers.

Welty, Eudora, 1909-. Critical studies

I. Title II. Series

$813^{\prime} .52$

ISBN 978-0-333-43709-4

ISBN 978-1-349-20012-2 (eBook)

DOI 10.1007/978-1-349-20012-2 


\section{Contents}

Acknowledgements vi

Editors' Preface vii

1 A Sheltered Life 1

2 A Generous Comic Muse 24

3 Apprenticeship $\quad 54$

4 Demeter and Kore in Mississippi 85

5 New Women 127

6 Welty's Affirmations 165

$\begin{array}{ll}\text { Notes } & 169\end{array}$

Bibliography 175

$\begin{array}{ll}\text { Index } & 177\end{array}$ 


\section{Acknowledgements}

I am indebted to the following for their support of this study: Paul Armstrong, Head of the Department of English at the University of Oregon; the Center for the Study of Women in Society at the University; and H. T. Holmes and the staff of the Department of Archives and History of the State of Mississippi in Jackson.

Friends and colleagues gave advice and careful readings of the manuscript as it evolved. My husband George Wickes is first among them, always my most demanding and illuminating editor. Suzanne Marrs welcomed me when I first went to Jackson in June of 1987 to work with Miss Welty's papers, and she has given judicious counsel since, particularly for the first, biographical, chapter of the study. Mary Wood and Paul Armstrong also read parts of the manuscript and provided guidance on matters of critical theory.

Finally I want to thank Eudora Welty for the kindness with which she welcomed me and talked with me about her work during my trips to Jackson in the summer of 1987. 


\section{Editors' Preface}

The study of women's writing has been long neglected by a male critical establishment both in academic circles and beyond. As a result, many women writers have either been unfairly neglected or have been marginalised in some way, so that their true influence and importance has been ignored. Other women writers have been accepted by male critics and academics, but on terms which seem, to many women readers of this generation, to be false or simplistic. In the past the internal conflicts involved in being a woman in a male-dominated society have been largely ignored by readers of both sexes, and this has affected our reading of women's work. The time has come for a serious reassessment of women's writing in the light of what we understand today.

This series is designed to help in that reassessment.

All the books are written by women because we believe that men's understanding of feminist critique is only, at best, partial. And besides, men have held the floor quite long enough.

EVA FigES

ADELE KING 